\title{
Stanovení úrovně dna vodních děl z historických projektových dokumentací
}

\section{MARTIN CALETKA, PAVLA ŠTĚPÁNKOVÁ}

\author{
Klíčová slova: dno - georeferencování - GIS - morfologie - sedimenty - sonar - vodní díla
}

\section{SOUHRN}

Monitoring a údržba vodních děl vyžadují znalost jejich referenčního stavu charakterizujícího návrhové parametry. Referenční stav je odvozován primárně z dostupných projektových dokumentací, které jsou vhodně zvolenými metodami převedeny na digitální model terénu dna. Aktuální úroveň dna je stanovována pomocí sonarových prostředků. Rozdílovou analýzou jednotlivých datových sad, které budou výhledově ukládány do specializovaného informačního systému, bude možné provádět efektivní rízení monitoringu údržby.

Předložená práce na př́kladech vybraných pilotních lokalit shrnuje problematické aspekty identifikované při georeferencování digitalizovaných historických situačních výkresů, které mohou negativně ovlivňovat korektní lokalizaci jednotlivých částí vodních děl a následnou analýzu morfologických změn. $\checkmark$ pilotní lokalitě vodní nádrže je rovněž hodnocena přesnost měřicí technologie použité při zaměřování dna.

\section{ÚVOD}

Problematika sedimentů predstavuje jedno z významných témat státní politiky v oblasti vodního hospodářství. Správci vodních děl musí podle $§ 59$ zákona č. 254/2001 Sb., o vodách [1], plnit povinnosti a dodržovat podmínky, za kterých bylo vodní dílo povoleno a uvedeno do provozu. Hlavní cíle státní politiky v oblasti vodního hospodářství vycházejí z Vodní rámcové směrnice 2000/60/ES [2] a z obnovené Strategie EU pro udržitelný rozvoj z roku 2006.

Na evropské úrovni je patrná aktivita směrem k problematice sedimentů především v souvislosti s vnitrozemskou plavbou, potažmo rozvojem a údržbou Transevropské dopravní sítě (TEN-T). Ve snaze o implementaci Integrovaného evropského akčního plánu pro vnitrozemskou vodní plavbu z roku 2006 vznikl dokument Good Practice Manual on Inland Waterway Maintenance [3]. Uvedená práce má charakter komplexního manuálu údržby vodních cest vycházející z př́ikladů dobré praxe. Pozornost je rovněž soustředěna na vliv sedimentů na kvalitu vod, a to zejména zásluhou tzv. SedNet (European Sediment Network) [4].

Během dlouhého období existence vodních děl dochází k přirozeným i antropogenně podmíněným a akcelerovaným morfologickým změnám jejich dna, resp. koryta. V exponovaných částech může docházet k zahlubování, naopak v oblastech s nižší dynamikou proudění jsou unášené plaveniny deponovány. Tyto změny mají v konečném důsledku dopad na průtočnou kapacitu a schopnost vodního díla (VD) plnit funkce, pro které bylo vybudováno. Proto je potřebné průběžně monitorovat stav vodních děl a v prípadě potřeby přistoupit k potřebným opatřením.
Při monitorování stavu vodních děl či jezer z hlediska erozně-akumulačních procesů se $v$ současné době stále více uplatňují moderní metody bezkontaktního průzkumu pomocí sonarů, např. [5-10], či zařízení AUV (z angl. Autonomous Underwater Vehicle) [11]. Aby bylo možné posoudit míru změn morfologie VD, je třeba vycházet z porovnání s informacemi o návrhovém stavu uvedeném $\checkmark$ patřičné projektové dokumentaci VD. Ty zahrnují technické zprávy a situační plány $v$ tištěné podobě, mnohdy $v$ různých formátech a $v$ různé kvalitě „čitelnosti". Tyto podklady je nezbytné převést do digitální podoby a provést jejich lokalizaci (georeferencování) do souřadnicového systému. Problematika digitalizace georeferencování historických map je široce popsána v odborné literatuře, např. [7, 12-14]. Praxe ukazuje, že jednotlivé podklady při zpracovávání vyžaduji často individuální prístup vzhledem k době, kdy vznikly a s jakou přesností a pečlivostí byly vyhotoveny.

Předložený článek popisuje na př́kladech pilotních lokalit postupy zvolené pro digitalizaci projektových dokumentací vybraných vodních děl různého stáři a velikosti. Výsledky těchto procesů jsou pak využity při prvotním srovnání získaného digitálního návrhového stavu VD se stavem současným, který reprezentuji výsledky sonarového měření.

\section{METODIKA}

\section{Návrhový stav}

Návrhový stav vodních děl shrnuje technická dokumentace. Většina podkladů je staršího data a je $k$ dispozici pouze $v$ tištěné podobě $v$ různých formátech. Některé z nich jsou často poškozené, popř. hưre čitelné. Digitalizace situačních výkresů proto probíhala po částech s dostatečnými překryvy, které umožnily navázat jednotlivé díly na sebe.

Přesná lokalizace jednotlivých částí výkresové dokumentace, tzv. georeferencování, byla prováděna $\vee$ prostředí ESRI ArcGIS. Zpracováním po jednotlivých dílech bylo eliminováno riziko přenesení možných chyb georeferencování, které vyplývá z rozlišení skenovaných snímků, z jedné části výkresu do dalších. Jako vlícovací body byly využity objekty či jejich části zakreslené v situačních výkresech, které bylo možné identifikovat na současných mapách. Obvykle se jedná o rohy budov a význačné tvary projektovaných mostů, hrází či jezů. Pokud to bylo možné, bylo využito rovněž hranic parcel. V některých částech výkresů se však potřebné záchytné body nevyskytovaly. V takových prípadech byla lokalizace části výkresu provedena pomocí překryvu se sousedními výkresy a s využitím výrazných terénních tvarů, jako jsou charakteristické ohyby vrstevnic ve stržích apod. Následně byly z takto upravených podkladů do vektorových formátů preváděny základní informace o morfologii dna pilotních lokalit podle návrhového stavu. 


\section{Vodní nádrže}

$\checkmark$ případě vodních nádrží byly z georeferencovaných situačních výkresů do mapové vrstvy vykresleny linie vrstevnic, jimž byla přiřazena odpovídající nadmořská výška v souladu s použitým výškovým systémem (obr. 1).

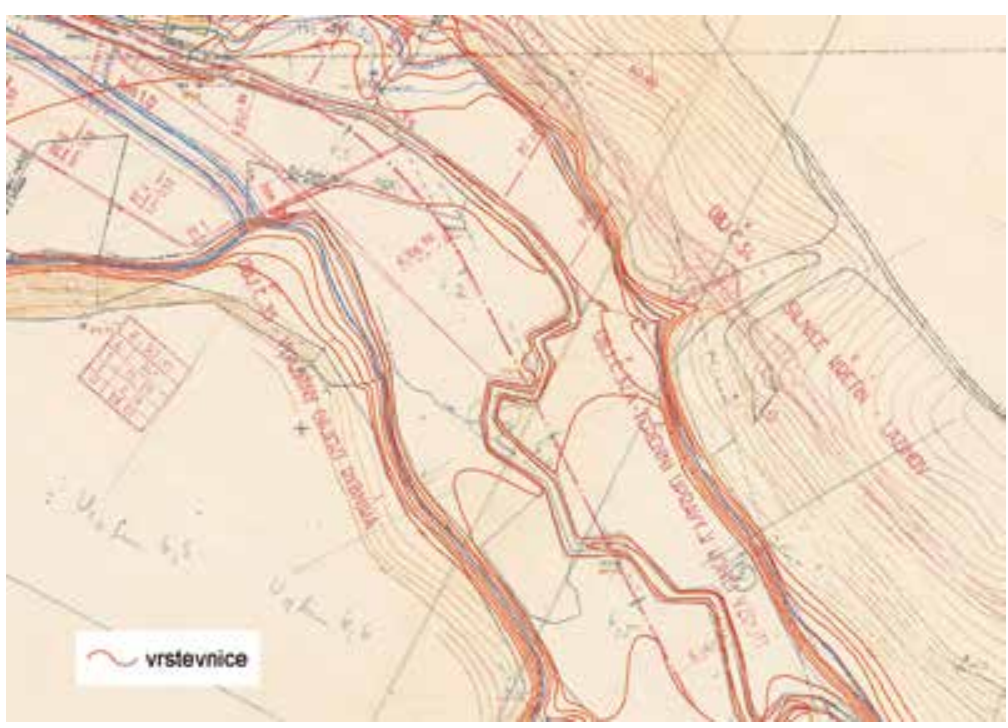

Obr. 1. Ukázka digitalizace vrstevnic na podkladu situačního výkresu části zátopy vodní nádrže Letovice

Fig. 1. An example of the contour vectorization on the basis of the situational plan of the Letovice Dam

\section{Úseky vodních toků}

Úprava koryt vodních toků je v situačních výkresech obvykle znázorněna osou koryta a polohou príčných profilu (obr. 2). Tyto profily jsou zaznamenány samostatně jako linie s lomovými body, z nichž některé mají uvedenu hodnotu nadmořské výšky $Z$ podle použitého výškového systému. Každý výkres má znázorněnu referenční hladinu $v$ nadmořské výšce $Z_{0}$ (obr. 3). Podle této referenční hladiny byly digitalizované výkresy vyrovnány do vodorovné polohy, jednotlivé lomové body uloženy do bodové vrstvy a stanoveny jejich relativní kartézské souřadnice $X, Y$. Pomocí známých nadmořských výšek některých bodů, referenční hladiny a jejich vzdáleností vyjádřených vzájemnými rozdíly souřadnic $X, Y$ bylo definováno měřitko zakreslení daného profilu. To pak umožňuje dopočítat nadmořské výšky $Z$ bodů, u nichž tento údaj nebyl uveden, a také vzdálenosti $d$ jednotlivých bodů od osy príčného profilu.

Následná část výpočtu spočívá v určení polohy (kartografických souřadnic) jednotlivých lomových bodů přičných profilů v mapě s využitím mapové vrstvy přícných profilů vykreslených ze situačního výkresu a také mapové vrstvy průsečíků príčných profilů s osou toku (blíže viz obr. 2). Dvojice koncových bodů každého příčného profilu určují směrový vektor u pomyslné prímky, na níž daný prríčný profil leží. Snadným prepočtem je možné odvodit normálový vektor n této přímky, jejíž obecná rovnice má tvar:

$$
p: n_{1} X+n_{2} Y+c=0
$$

$n_{1^{\prime}} n_{2}$ je souřadnice normálového vektoru $n$,

$X, Y \quad$ kartografické souradnice libovolného bodu ležícího na prímce, c konstanta dané prímky.

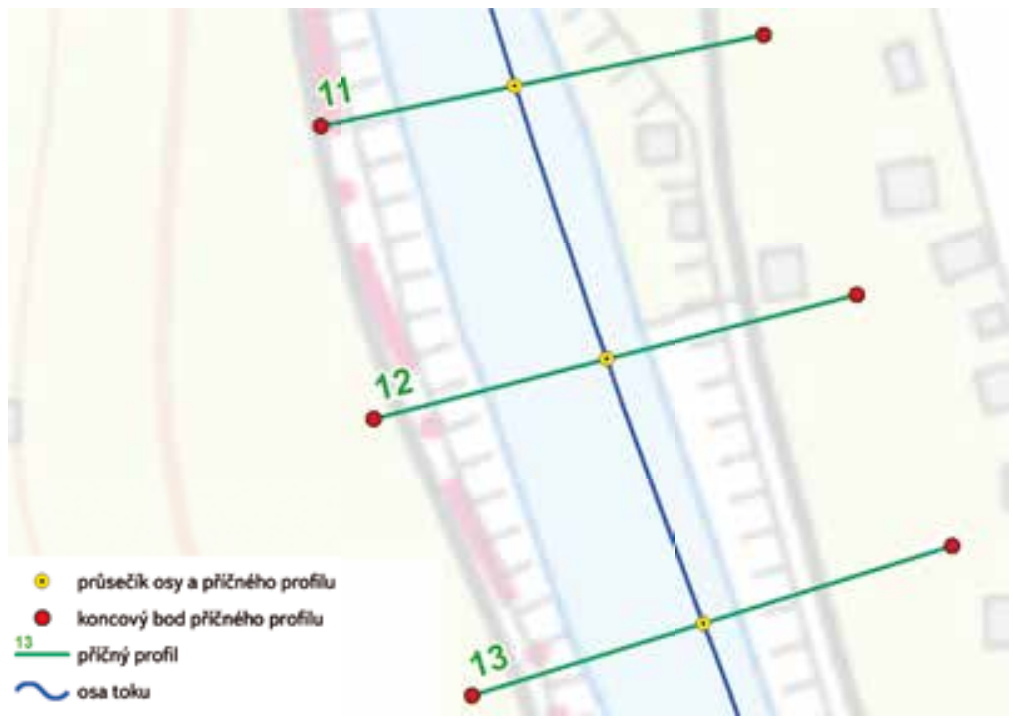

Obr. 2. Příčné profily definované koncovými body a průsečíky s osou toku podle projektové dokumentace

Fig. 2. Position of cross profiles defined by their intersection with the channel's axis according to the situational plan

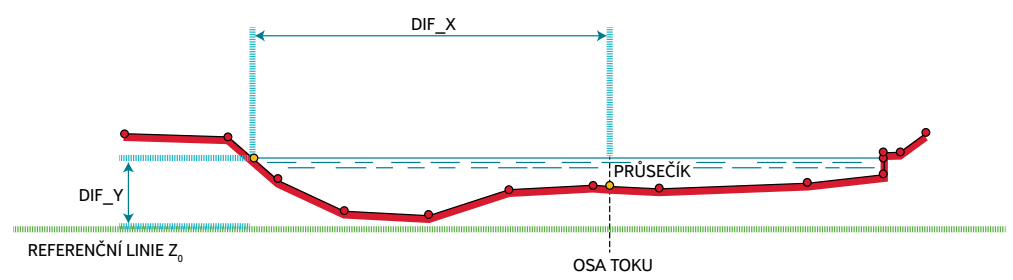

Obr. 3. Schéma stanovení nadmořské výšky a vzdálenosti lomových bodů príčného profilu od průsečíku s osou

Fig. 3. Principle of the fracture points' positioning in a cross profile based on the distance from the intersection of the channel axis with the cross profile; calculation of the fracture points' altitude

Při znalosti zeměpisných souřadnic $X_{0^{\prime}} Y_{0}$ průsečíku př́ičného profilu s jeho osou a na základě vzdálenosti $d$ jednotlivých lomových bodů príčného profilu od průsečíku je možné sestavit soustavu dvou rovnic o dvou neznámých $X_{i^{\prime}} Y_{i}$ (tj. hledané kartografické souřadnice konkrétního lomového bodu) ve tvaru:

$$
\begin{aligned}
& 0=n_{1} X_{i}+n_{2} Y_{i}+c \\
& d=\sqrt{\left(X_{i}-X_{0}\right)^{2}+\left(Y_{i}-Y_{0}\right)^{2}}
\end{aligned}
$$

Úpravou této soustavy je získána kvadratická rovnice, jejímž řešením jsou dva body ležící na prríčném profilu ve stejné vzdálenosti od průsečíku s osou. Z této dvojice bodů je vybrán ten, který skutečně leží na příčném profilu. Využito bylo atributu vyjadřujícího príslušnost ke straně ( $P$ nebo $L$ ) příčného profilu a dvou polygonů pokrývajících dostatečně široký prostor v okolí koryta. Oba polygony se dotýkají svými hranicemi a kopírují prítom osu koryta. Hledané body leží $\checkmark$ polygonu s totožným označením strany (obr. 4). 


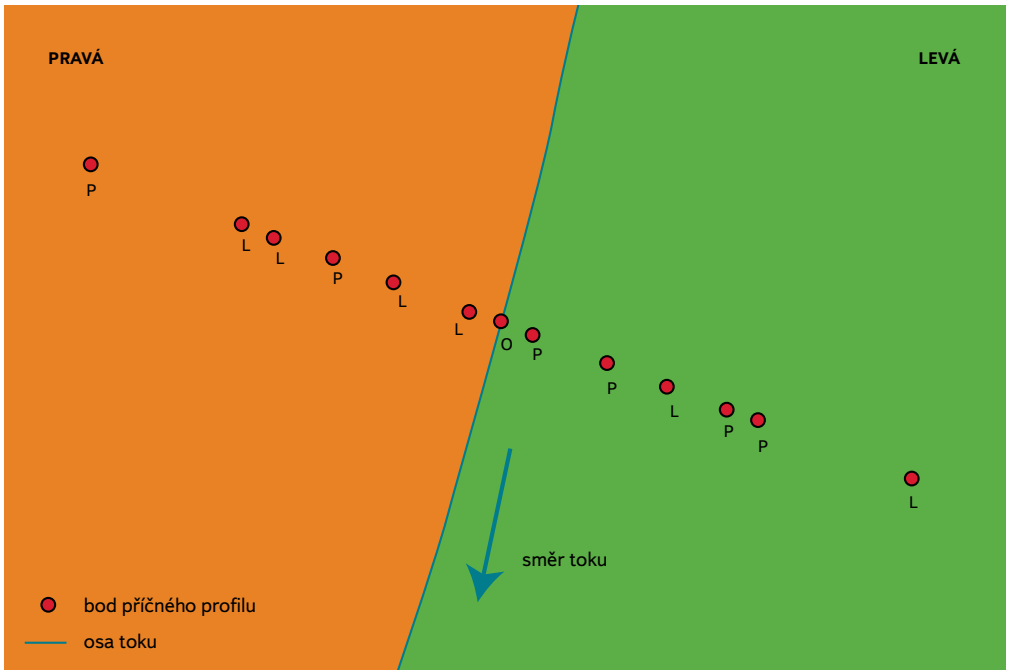

Obr. 4. Rozložení vypočítaných bodů vzhledem k jejich príslušnosti k pravé či levé straně vǔči ose toku ( $\mathrm{O}$ - průsečík s osou toku)

Fig. 4. Spatial distribution of the calculated fracture points, considering their affiliation to the right/left side from a channel's axis

Digitalizované přičné profily byly následně použity k vytvoření digitálního povrchu dna, resp. koryta, podle návrhového stavu. Body byly importovány do prostředí HEC-RAS, kde byla z příčných profilů vytvořena spojitá geometrie koryta toku, a to tak, že byly propojeny charakteristické lomové body, a na takto vzniklé spojnice byly umístěny meziprofily s rozestupem $5 \mathrm{~m}$ (obr. 5). V ojedinělých prípadech bylo nutné automatické propojení poupravit, aby tvar koryta netvořil překážku ve směru proudění.

Z prostředí HEC-RAS byla vytvořená geometrie přenesena do prostředí ESRI ArcGIS, kde byla s využitím doplňku HEC-Geo RAS dále zpracována do podoby nepravidelné trojúhelníkové sítě TIN (triangulated irregular network) a následně prevedena na rastr s velikostí buňky 0,5 m. Stanovení tohoto rozlišení vychází ze sítě bodů zaměřených prì echolokaci dna.

\section{Současný stav}

Měření batygrafie vodních děl bylo provedeno plavidlem CAPEREA (obr. 6) vycházejícím ze sériově vyráběného typu Sunchser 7518, poháněného dvojicí spřažených elektromotorů. Plavidlo bylo vybaveno skupinou zařízení pro určování zeměpisné polohy, senzorem zajištujuícím korekci náklonu podél hlavní a vedlejší osy a zařízením pro měření rychlosti zvuku a jeho profilu ve vodním sloupci. Samotné měření batygrafie bylo prováděno s pomocí dvou sonarů.

Sonarová jednotka GeoSwatch Plus Compact 500 kHz je systém určený pro měření batygrafie mělkých vod do hloubky 50 m. Umožňuje vytvářet digitální model dna se statistickou presností 1,5 mm. Sonar SES-2000 Compact je schopen pronikat do mělkých geologických vrstev a umožňuje zaznamenávání podélného profilu sedimentovaných vrstev a měření jejich mocnosti. Je založen na vysílání dvou různých frekvencí, které spolu interagují a pomocí jejich sumy či rozdílu je možné získat informaci o stratigrafii dna.

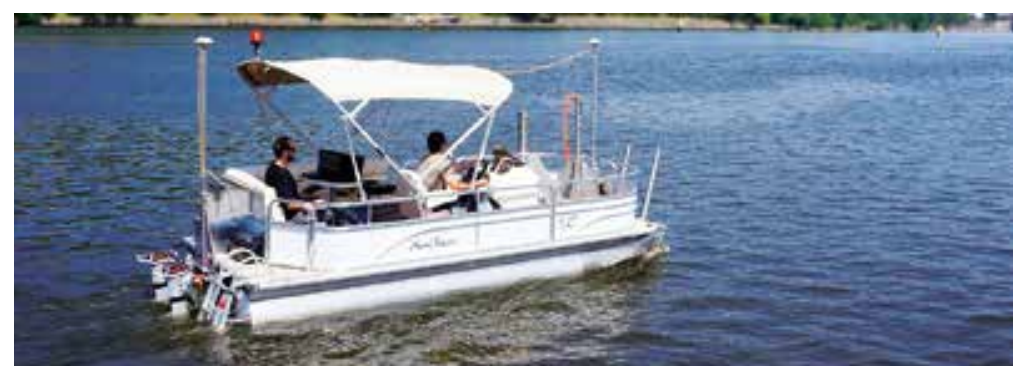

Obr. 6. Multifunkční plavidlo CAPEREA

Fig. 6. Multipurpose watercraft CAPEREA used for the sonar measurements of bottom

Výstupem měření batygrafie je mračno bodů obsahujících údaje o úrovni dna v dané pozici (tj. kartografické souřadnice a nadmořskou výšku). Z této bodové vrstvy byla vytvořena nepravidelná trojúhelníková sít (TIN), která byla následně převedena na rastr s rozlišením 0,5 m. Uvedený postup je znázorněn na obr. 7.

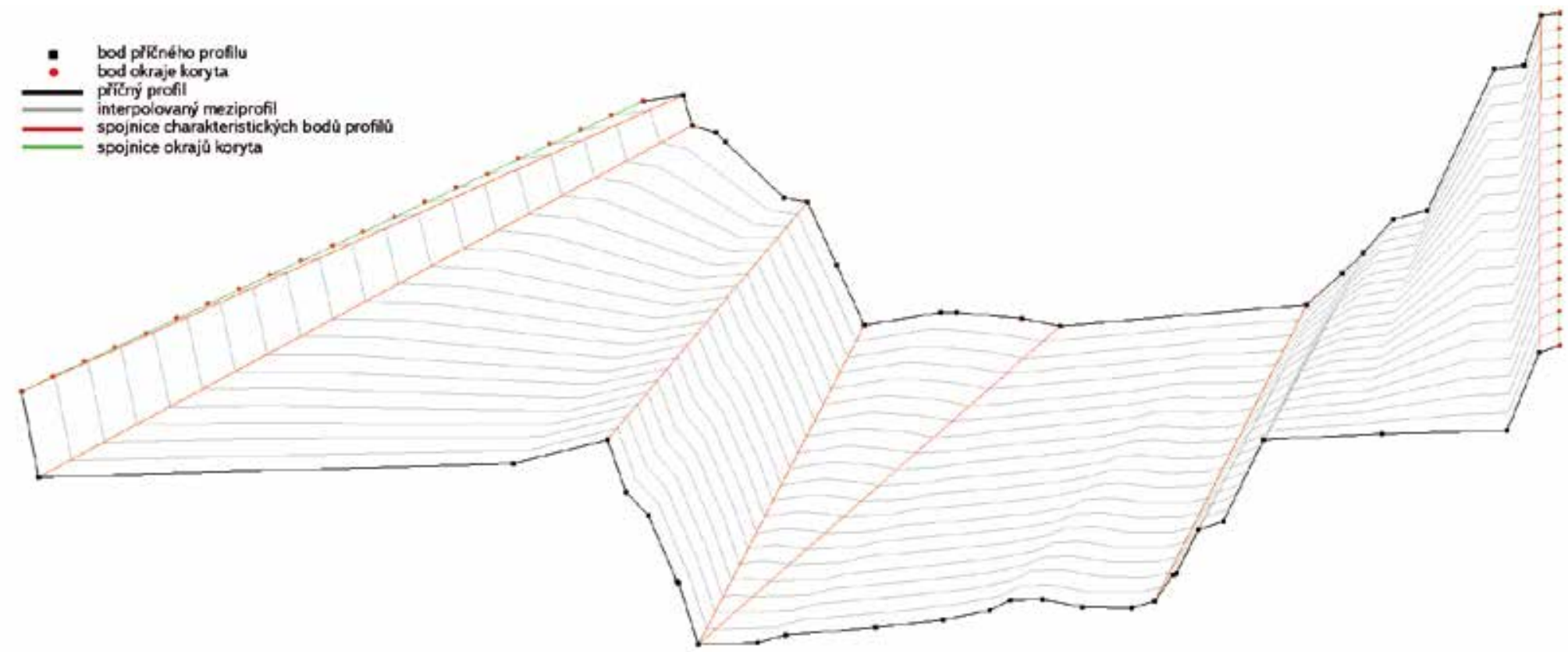

Obr. 5. Vytváření 3D koryta v prostředí HEC-RAS

Fig. 5. Creation of the 3D model of a channel using HEC-RAS 

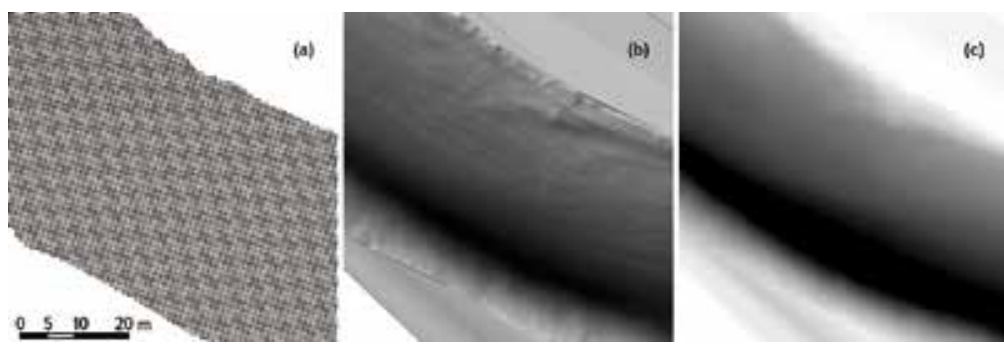

Obr. 7. Postup převodu bodové vrstvy z echolokačního měření části úseku vodního toku (a) na nepravidelnou trojúhelníkovou sít (b) a rastr s rozlišením 0,5 m (c)

Fig. 7. Transformation of the point layer from the sonar measurements of a channel's bottom (a) into triangulated irregular network (TIN) (b) and into raster with grid size of $0.5 \mathrm{~m}$ (c)

\section{Pilotní lokality}

K otestování postupu digitalizace byl primárně vybrán úsek reky Moravy ve vzdutí nad jezem v Kroměříži po jez v Bezměrově, resp. úsek mezi ř. km 179,230 a 182,515 (obr. 8).

Na vodní nádrži Letovice bylo za účelem verifikace sonarového měření provedeno geodetické měření části dna. Měření probíhalo nedaleko obce Vranová při pravém břehu zátopy $\vee$ pásu přibližně $200 \mathrm{~m}$ dlouhém a $30 \mathrm{~m}$ širokém (obr. 9). Měrná lat’ byla z plavidla spouštěna na úroveň dna, jehož nadmořská výška byla poté zaměřena. Podobné kontrolní zaměěení bylo provedeno také $\checkmark$ pracích Kubinského a kol. [7, 8], ovšem s tím rozdílem, že měrná tyč byla opatrena plochou patkou.

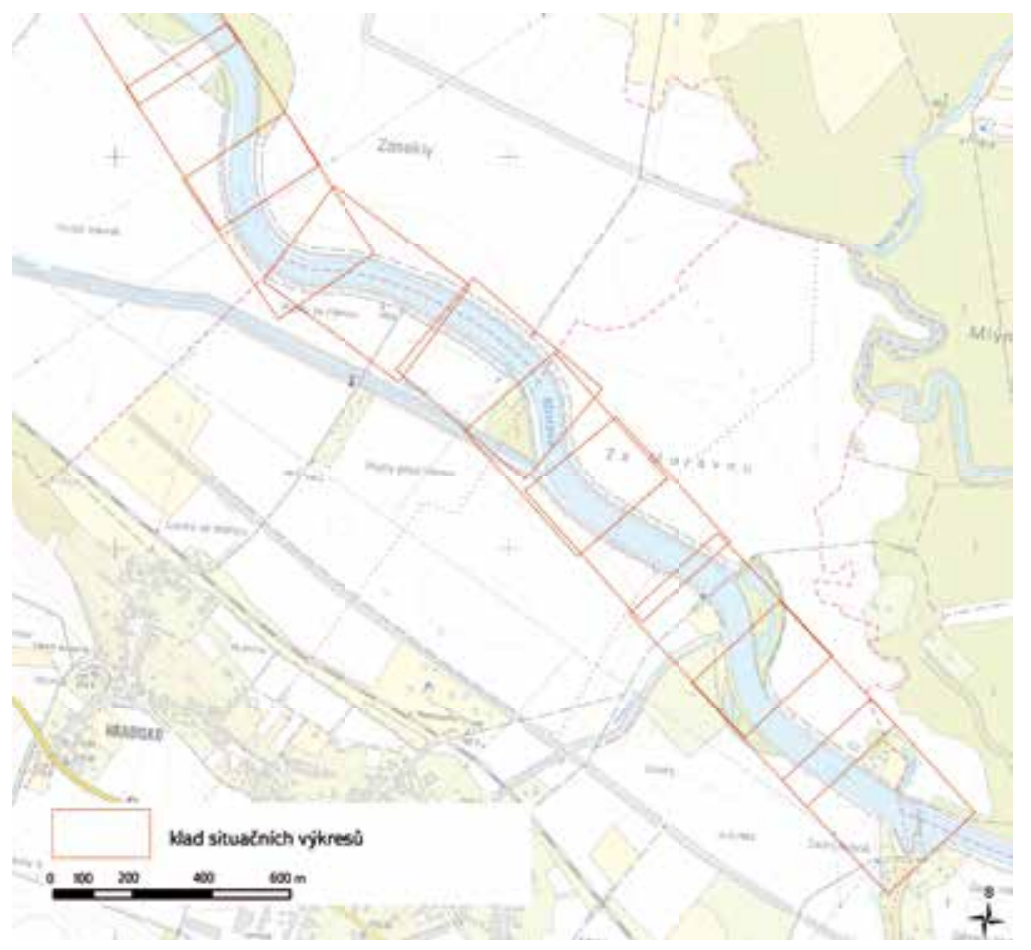

Obr. 8. Zájmový úsek řeky Moravy ve vzdutí jezu mezi Kroměříží a Bezměrovem s vyznačením polohy jednotlivých částí situačního výkresu

Fig. 8. Study river reach of the Morava River between Kroměřiž and Bezměrov with the indication of individual parts of the situational plan

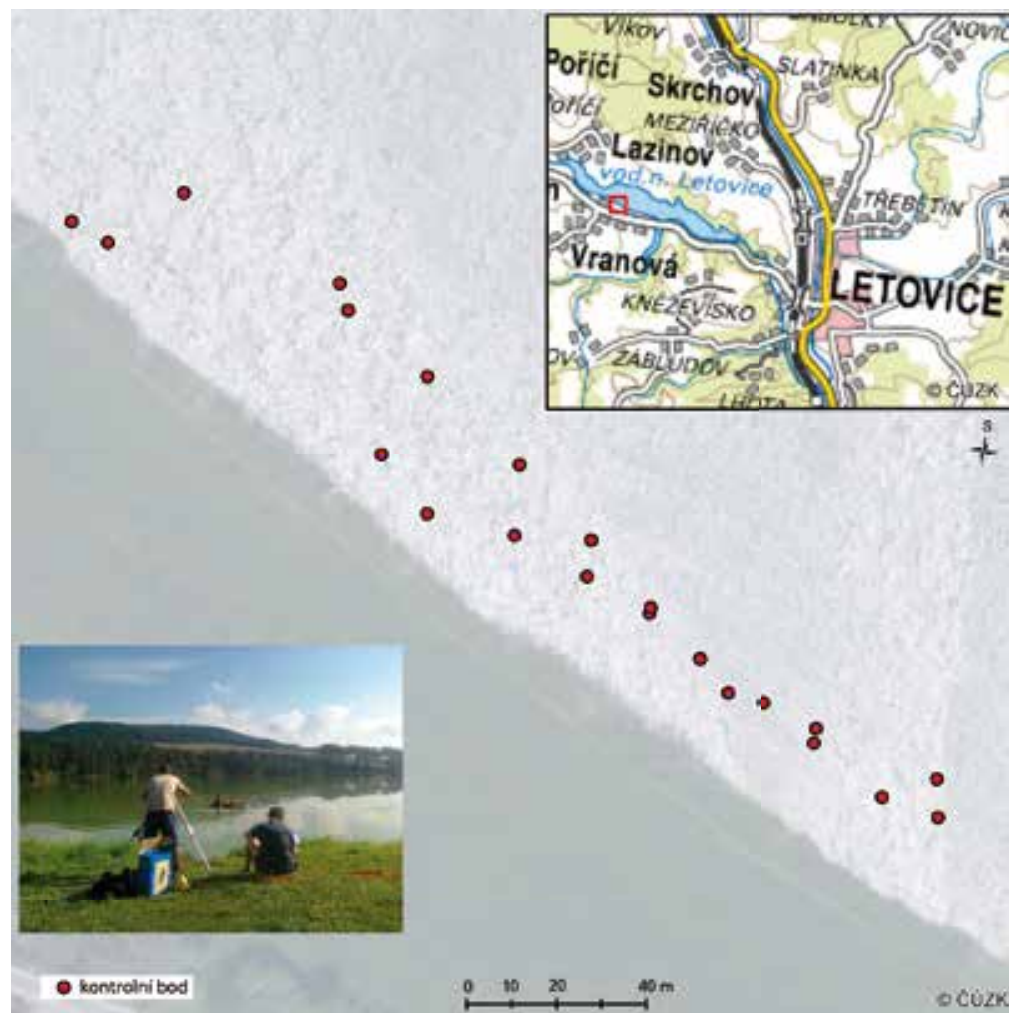

Obr. 9. Kontrolní geodetické měření úrovně dna části vodní nádrže Letovice Fig. 9. Verification of the sonar measurement of a bottom in a near-shore zone at the Letovice Dam - geodetic measurement

\section{VÝSLEDKY}

\section{Návrhový a současný stav dna}

Popis změny morfologie dna vodních děl za účelem následného vyhodnocení dopadu na jejich funkce a posouzení vhodnosti a efektivity potenciálních zásahů vyžaduje znalost návrhového stavu, k němuž je vztahována současná úroveň dna. Vzhledem ke stáří a povaze situačních výkresů může být jejich digitalizace a správná lokalizace obtižná. Postup, který Ize považovat za obecně správný a přesný, je popsán v metodice. Při praktickém zpracování konkrétních podkladů však místy vyvstaly určité problémy.

U historických situačních výkresů je často obtížně zjistitelné, v jakém souřadném systému byly vyhotoveny, což potvrzují i další autoři [12, 15]. Především $u$ delších koryt toků $v$ důsledku toho může docházet $k$ deformaci georeferencovaného podkladu a k odchylování koryt, byt̉ mírnému, od jejich skutečné polohy. Zejména na okrajích koryta proto mohou být při rozdílové analýze zaznamenávány zdánlivé prohlubně či elevace (obr. 10). K tomuto pristupuje i skutečnost, že původně projektované úpravy nemusely být realizovány v celém rozsahu (tzn. po celé délce a na obou stranách koryta). V prípadech, kdy průběh původního koryta byl velmi podobný průběhu koryta navrhovaného avšak nerealizovaného, může být obtížné rozhodnout, kterou z variant považovat za skutečný návrhový stav. 


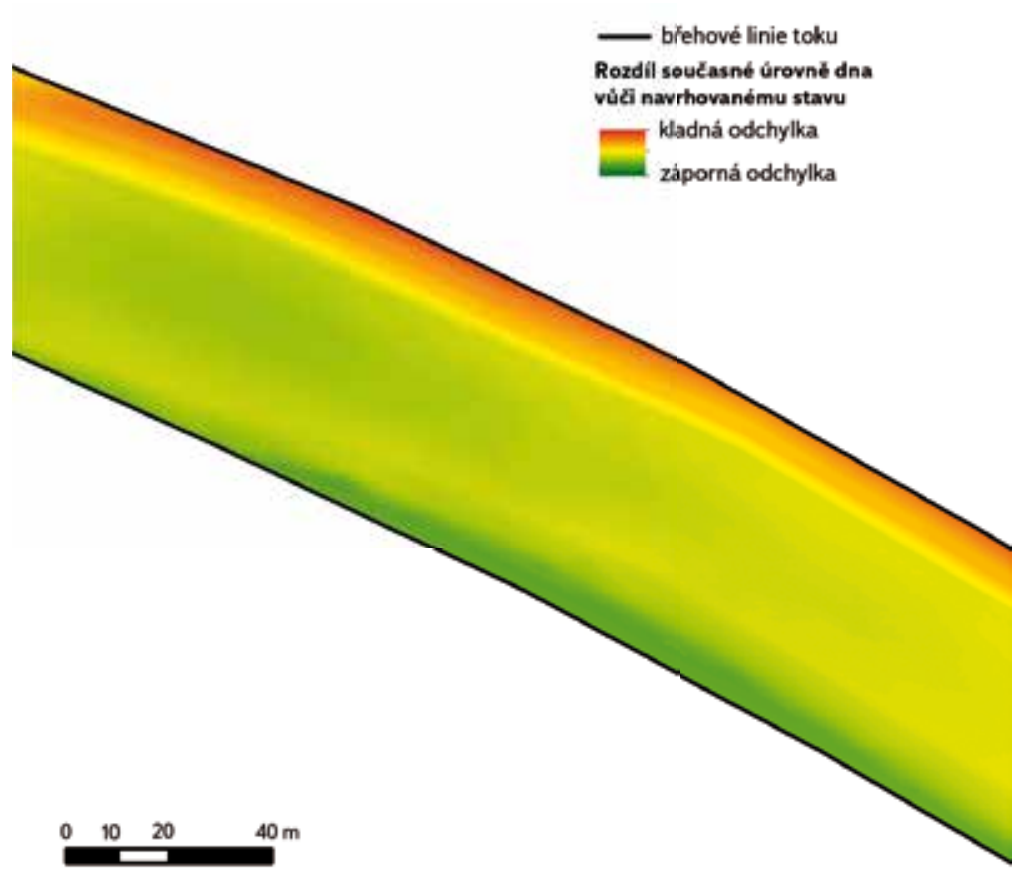

Obr. 10. Zdánlivé elevace a prohlubně na okrajích měřeného koryta zpưsobené vychýlením koryta při georeferencování situačního výkresu

Fig. 10. Apparent elevations and depressions at the edges of the river channel caused by the channel deviation when georeferencing the situational plan

Přesnou lokalizaci historických situačních plánů Ize provést s pomocí důkladné rekognoskace konkrétního úseku. To představuje geodetické zaměření břehových linií, sklonů břehů, v ideálním prípadě i zaměření topografie dna. Podle nich je následně možné korektně umístit prríčný profil a jedině tak Ize určit, zda byla úprava koryta podle projektu provedena, případně v jakém rozsahu. Ani tento postup však nemusí vést k jednoznačnému výsledku. Břehy totiž mohu být za dlouhé období silně ovlivněny prorůstajícími kořeny stromů, erozí nebo dodatečnými změnami v opevnění, což se může projevit ve změně tvaru průtočných profilů. Přesto zůstává posouzení kombinace morfologických charakteristik koryta a následná manuální korekce umístnění konkrétního příčného profilu jediným způsobem, jak provést jeho lokalizaci co nejpřesněji.

\section{Přesnost echolokátoru}

Využití sonaru jako spolehlivého zdroje dat bylo prezentováno $v$ raadě prací věnujících se monitoringu dna a erozně-akumulačních procesů probíhajících v prírodních jezerech (např. [6, 10, 12]), vodních nádržích (např. [7, 8]) i vodních tocích (např. [11, 16]). V rámci této práce byla přesnost výstupư měření echolokátoru testována v pilotní lokalitě na vodní nádrži Letovice. Odchylky zaměřených úrovní dna jsou uvedeny na obr. 11, z něhož je patrné, že nepřevažují kladné ani záporné hodnoty, z nichž by bylo možné usuzovat na systematické pod-či nadhodnocovaní úrovně dna echolokačním měřením. Tuto nejednoznačnost je možné odůvodnit velkou členitostí dna, v důsledku které mưže nevýznamný posun měrné latě z důvodu obtížné dlouhodobé stabilizace plavidla vést $\mathrm{k}$ naměření odchýlených hodnot [8]. Obecným problémem při hodnocení úrovně dna touto metodou je rovněž zrnitostní struktura zvodnělých sedimentů, projevující se jejich rozličnou tuhostí vůči spouštěné měrné lati. V případě měkkých sedimentů může docházet k jejímu zaboření do dna a zaměření větší hloubky oproti skutečné. Tento problém by bylo možné jistě alespoň částečně řešit opatřením měrné tyče zmíněnou plochou patkou.

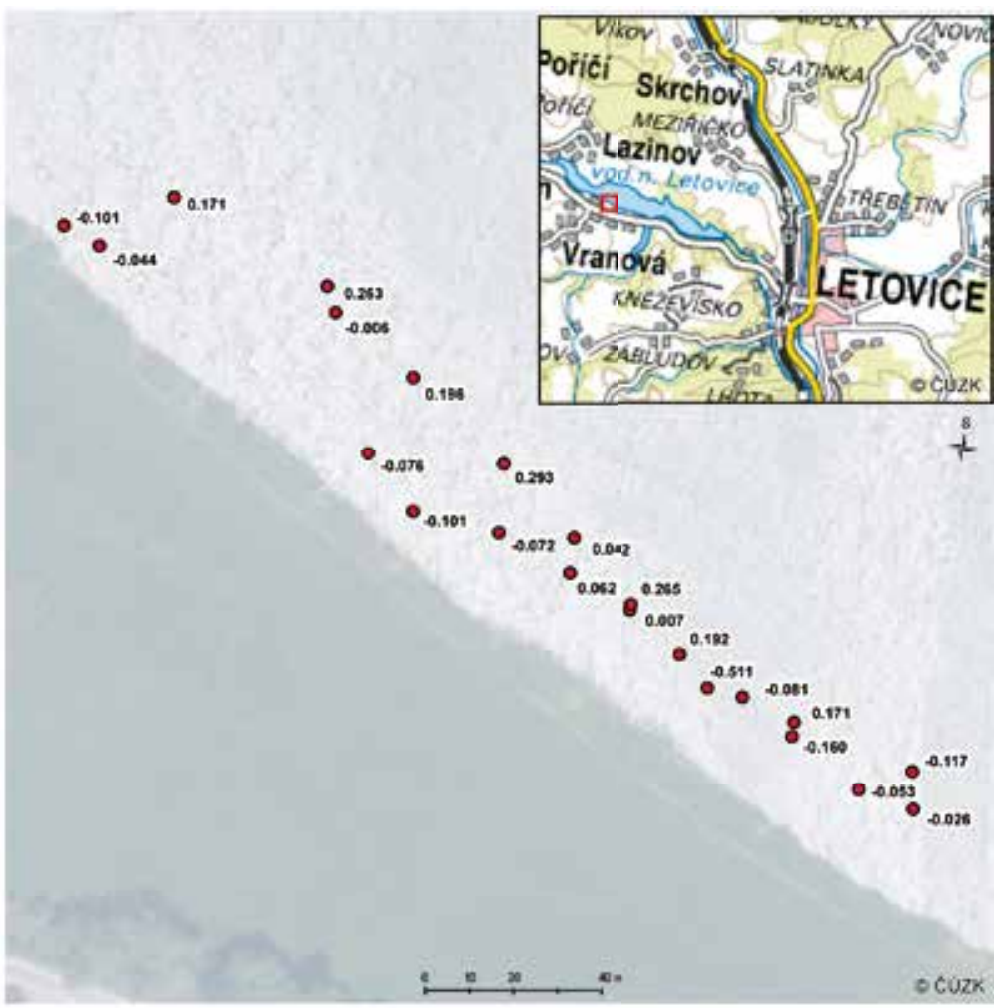

Obr. 11. Výsledek porovnání nadmořských výšek v kontrolních bodech vưči úrovni dna zaměřeného echolokátorem v pilotní lokalitě VN Letovice pobliž obce Vranová Fig. 11. Differential comparison of the altitudes from the verification measurement and the altitudes measured using the sonar in the neer-shore zone of the Letovice Dam

\section{Obecné hodnocení morfologických změn}

Porovnáním současné úrovně dna s návrhovým stavem umožnilo identifikovat erozně-akumulační procesy probíhající ve vzdutí jezu v Kroměřiži na řece Moravě. Z provedených měření jsou patrná především výrazná zahloubení dna podél konkávních břehů, kde maximální hloubky dosahují hodnot přes $7 \mathrm{~m}$. Nápadné prohlubně se vyskytují také při vyústěních prítoků do hlavní trati a za mostními piliríi. V uvedených místech dochází ke vzniku turbulentního proudění, v němž je sedimentace unášených částic znemožněna. Obecně je však žretelné, že prevažujícím jevem je akumulace plavenin, což je způsobeno zpomalením proudění, a tedy sníženou transportní kapacitou toku v tomto úseku.

Uvedeným postupem je možné stanovit i konkrétní kubatury deponovaného materiálu. Vzhledem k výše uvedeným problematickým aspektům je však nutno nejprve všechny nejednoznačnosti odstranit. Posouzení potřebnosti př́padných zásahů však musí vycházet z podrobného vyhodnocení jednotlivých částí koryta, $v$ nichž mohou probíhat odlišné, specifické, erozně-akumulační procesy. Z hlediska logistického je také nutno uvažovat, že skutečná kubatura sedimentů může být nižší z důvodu jejich zvodnění.

\section{Poděkování}

Článek vznikl v rámci zpracováni projektu KUS QJ1520267 Systém řizení a údržby VH infrastruktury financovaného z prostředkü Ministerstva zemědělství ČR. 


\section{Literatura}

[1] Zákon č. 254/2001 Sb. o vodách a o změně některých zákonů (vodní zákon).

[2] Směrnice Evropského parlamentu a Rady 2000/60/ES ze dne 23. řijna ustavující rámec pro činnos Společenství v oblasti vodní politiky.

[3] Viadonau. Platina 2, Good Practice Manual on Inland Waterway Maintenance. Implementing the European Action Programme for the promotion of inland waterway transport (NAIADES 2), 2016.

[4] SedNet European Sediment Network [online]. [cit. 30. 9. 2017]. Dostupné z: http://sednet.org/

[5] MOORMAN, B.J. and MICHEL, F.A. Bathymetric mapping and sub-bottom profiling through lake ice with ground-penetrating radar. Journal of Paleolimnology, 1997, vol. 18, No. 1, p. 61-73.

[6] WAPLES, J.T., PADDOCK, R., JANSSEN, J., LOVALVO, D., SCHULZE, B., KASTER, J., and KLUMP, J.V. High resolution bathymetry and lakebed characterization in the nearshore of Western Lake Michigan. Journal of Great Lakes Research, 2005, vol. 31, p. 64-74.

[7] KUBINSKÝ, D. a WEIS, K. Zmeny retenčního objemu v priestore vodnej nádrže (tajchu) Evička. Acto Environmentalica Universitatis Comenianae, 2013, roč. 21, č. 1, s. 18-26.

[8] KUBINSKY, D., WEIS, K. a LEHOTSKÝ, M. Zmeny ekosystémov a retenčních charakteristík Belianskej vodnej nádrže a okolia. Geografický časopis, 2014, roč. 66, č. 2, s. 161-175.

[9] WEIS, K. a KUBINSKÝ, D. Analýza zmien objemu Halčianskej vodnej nádrže vplyvom erózie jako podklad pre manažment v povodí. Geografie, 2014, roč. 119, č. 2, s. 126-144.

[10] SILJEG, A., JURISIC, M., and MARIC, I. Bathymetric Measures of the Lakes Skradinski Buk. Geodetski list, 2016, vol. 70, No. 3, p. 231-252.

[11] SOČUVKA, V. a VELÍSKOVÁ, Y. Automatizované monitorovanie morfológie dna vodných tokov. Acta Hydrologica Slovaca, 2014, roč. 16, tematické číslo, s. 108-113.

[12] ZLINSZKY, A. and MOLNAR, G. Georeferencing the First bathymetric Maps of Lake Balaton, Hungary. Acta Geodetica et Geophysica Hungarica, 2009, vol. 44, No. 1, p. 79-94. DOl: 10.1556/ AGeod.44.2009.1.8.

[13] ZLINSZKY, A. and TIMÁR, G. Historic maps as a data source for socio-hydrology: a case study of the Lake Balaton wetland system, Hungary. Hydrol. Earth Syst. Sci., 2013, vol. 17, No. 11, p. 4589-4606 DOl: 10.5194/hess-17-4589-2013

[14] BEYER, T. Advanced methods for the stimation of an unknown projection from a map. GEOINFORMATICA, 2014, vol. 20, No. 2, p. 241-284. DOI: 10.1007/s10707-013-0200-4.

[15] MOSSA, J. and MCLEAN, M. Channel planform and land cover changes on a mine driver floodplain Applied Geography, 1997, vol. 17, p. 43-54.

[16] LUKÁČ, M. a HOLUBOVÁ, K. Hodnotenie morfologického vývoja koryta Dunaja na úseku Sap Szob. Acta Hydrologica Slovaca, 2015, roč. 16, tematické číslo, s. 114-123.

\section{Autoři}

Mgr. Martin Caletka

冈martin.caletka@vuv.cz

Mgr. Pavla Štěpánková, Ph.D.

凶pavla.stepankova@vuv.cz

Výzkumný ústav vodohospodářský T. G. Masaryka, v. v. i., pobočka Brno

Příspěvek prošel lektorským řízením.

\section{BOTTOM LEVEL ESTIMATION OF WATER MANAGEMENT INFRASTRUCTURES FROM HISTORIC PROJECT DOCUMENTATIONS}

\section{CALETKA, M.; STEPANKOVA, P.}

TGM Water Research Institute, p. r. i., Branch Brno

Keywords: bottom - georeferencing - GIS - morphology sediments - sonar - water management infrastructures

Monitoring and maintenance of water management infrastructure require knowledge of their reference state characterizing their design parameters. The reference state is derived primarily from the available project documentation, which is appropriately chosen to be converted to a digital model of the bottom terrain. The current level of the bottom is determined by means of sonar technology. Differential analysis of individual datasets, which will be stored in a specialized information system, will allow an efficient maintenance and monitoring.

The presented work summarizes the problematic apsects identified in the georeferencing of the digitalized historic situational plans, which can negatively influence the correct localization of individual parts of waterworks and subsequent analysis of morphological changes of the bottom. The accuracy of the sonar technology applied for measuring the level of the botton is also assessed at a chosen study site. 